\title{
The floral smell of sanctity and the semiotics of the halo
}

\author{
Jenny Ponzo \\ Università di Torino, IT \\ jenny.ponzo@unito.it
}

\begin{abstract}
The hagiographic discourse often uses floral metaphors to describe spiritual qualities. This is the case for instance with Thérèse of Lisieux's autobiography, in which the saint compares herself to humble flowers, and in particular to the violet, which is not evident for her shape, but attracts the attention thanks to her scent. The same metaphor is developed by Pius XII in the discourse he pronounced in occasion of the beatification of Frère Bénilde in 1948. The violet is also one of the flowers the scent of which is connected to the charisma of the osmogenesis, which Catholic tradition describes as a particular gift of the saints consisting in being surrounded by an extremely good scent, which remains in the places where they go, on the objects that they touch, and sometimes emanates from the body even after death. The floral scent works in this case as an indexical sign. The osmogenesis can be compared with the concept of aura present in many cultures: the representation of a halo of fragrance can be interpreted as an alternative to a more frequent figurativization of the aura consisting in the representation of a luminous and coloured halo around the human body. The halo, both in its olfactory and visual variants, works as a particular semiotic system, entailing both spatial and temporal features.
\end{abstract}

\section{Keywords}

Osmogenesis; Halo; Sanctity; Charisma; Flowers; Body; Olfaction; Scent; Aura

\author{
Sommario/Content \\ 1. The perfume of the violet \\ 2. Virtues as flowers: the metaphoric icon \\ 3. The fragrance of sanctity: a metonymical index \\ 4. The semiotics of the "halo" \\ 5. Conclusion \\ Bibliographic references
}




\section{Dcula ${ }^{23}$}

Vol 21, No 23 (July 2020) • DOI: 10.12977/ocula2020-31

Jenny Ponzo | The floral smell of sanctity and the semiotics of the halo

\section{The perfume of the violet}

Saint Therese of Lisieux (1873-1897), canonized in 1925 and proclaimed Doctor of the Church in 1997, is one of the most influential and famous saints in the contemporary Catholic culture, connected to an ideal of humble and everyday sanctity. In her autobiography (Therese of Lisieux 1909: chapter 1), Therese narrates that, just before starting to write down her memories, she opens the Gospels randomly and her gaze falls upon the verse that reads "Jesus went up on a mountainside and called to him those he wanted, and they came to him" (Mark 3:13). She comments:

[These words] threw a clear light upon the mystery of my vocation and of my entire life, and above all upon the favours which Our Lord has granted to my soul. He does not call those who are worthy, but those whom He will. [...] I often asked myself why God had preferences, why all souls did not receive an equal measure of grace. I was filled with wonder when I saw extraordinary favours showered on great sinners like St. Paul, St. Augustine, St. Mary Magdalen, and many others, whom He forced, so to speak, to receive His grace. [...] Our Lord has deigned to explain this mystery to me. He showed me the book of nature, and I understood that every flower created by Him is beautiful, that the brilliance of the rose and the whiteness of the lily do not lessen the perfume of the violet or the sweet simplicity of the daisy. I understood that if all the lowly flowers wished to be roses, nature would lose its springtide beauty, and the fields would no longer be enamelled with lovely hues. And so it is in the world of souls, Our Lord's living garden. He has been pleased to create great Saints who may be compared to the lily and the rose, but He has also created lesser ones, who must be content to be daisies or simple violets flowering at His Feet, and whose mission it is to gladden His Divine Eyes when He deigns to look down on them. [...] I understood this also, that God's Love is made manifest as well in a simple soul which does not resist His grace as in one more highly endowed. [...] As the sun shines both on the cedar and on the floweret, so the Divine Sun illumines every soul, great and small, and all correspond to His care-just as in nature the seasons are so disposed that on the appointed day the humblest daisy shall unfold its petals. ${ }^{2}$

The figure of the humble violet also appears in Pius XII's discourse ${ }^{3}$ celebrating the beatification of the French monk Frère Bénilde (1805-1862):

Devant le saint dont la vie est un tissu d'actes éclatants de vertus surhumaines, de pénitences horrifiantes et, en même temps, de faveurs célestes des plus rares, on

1 This paper is part of the project NeMoSanctI, which has received funding from the European Research Council (ERC) under the European Union's Horizon 2020 research and innovation programme (grant agreement No 757314).

2 The English version of Therese autobiography is available here: <https://www. storyofasoul.com/>.

3 This discourse, delivered in French, is available here: <https://w2.vatican. va/content/pius-xii/fr/speeches/1948/documents/hf_p-xii_spe_19480405_ beatificazione-fratel-benildo.html>. 


\section{Dcula ${ }^{23}$}

Vol 21, No 23 (July 2020) • DOI: 10.12977/ocula2020-31

Jenny Ponzo | The floral smell of sanctity and the semiotics of the halo

demeure tellement ébloui que, dans cet éblouissement, alléguant l'impossibilité d'atteindre une si haute perfection, on se contente de répéter une fois de plus la formule devenue banale à force d'être commode, que les saints sont plutôt à admirer qu'à imiter. À l'inverse, devant le saint dont la vie se déroule toute unie sans épisodes impressionnants, sans exploits retentissants, plusieurs restent déçus et on la juge trop terne pour valoir la peine d'y chercher des exemples à suivre.

Dans un cas comme dans l'autre, ce qui a échappé à l'examen, c'est précisément l'essentiel. Comme on foule aux pieds, dans l'herbe où elle se cache, la violette, sans la reconnaître à son parfum, on dédaigne le parfum discret d'une vie sans éclat ; pas davantage on ne sait deviner, derrière le décor merveilleux d'une vie à grande allure, la réalité vivante, l'âme, pour s'efforcer non de copier les gestes, mais de vivre du même esprit, dont ces gestes furent animés.

Mieux peut-être que d'autres vies, celle de votre Frère Bénilde se manifeste-t-elle au premier coup d'œil admirable et imitable. Vie simple et uniforme, succession ininterrompue d'actions ordinaires dans un cadre plutôt modeste...

In this case too, the smell of the violet is described as a quality less apparent than the beauty of the forms and colors, and associated to a model of modest sanctity taking distance from spectacular manifestations, in line with an ideal of "ordinary" perfection characterizing the notion of sanctity promoted by the Church in the $20^{\text {th }}$ century (Ponzo and Rai 2019).

These two texts represent only a small example of a pervasive use of floral metaphors in Catholic modern discourse. In many cases, these metaphors focus specifically on the smell of flowers and attribute it a precise meaning associated to spiritual qualities. Given its extreme frequency and simplicity, the reference to flowers in religious discourse can seem almost banal, but this is only an appearance: in fact, the motif of the flower is complex and codified across different semiotic levels. In what follows, I do not have the pretension of providing a full picture of the uses and meanings of the flowery smells in the religious discourse. Rather, I will point out three different levels of codification of this motif in Catholic culture. The first concerns the metaphors involving flowers, both in verbal language and in ritual. The second is the olfactory interpretation of flowers, which bears a metonymic character. The third is a semiotic system involving the relationship between the perfume of flowers (and other celestial smells) and the body of the saints. These three dimensions of the codification of the flowers as signs are different in forms and substances of both expression and content and partially independent from each other, but at the same time also interconnected.

\section{Virtues as flowers: the metaphoric icon}

As the examples concerning Saint Thérèse of Lisieux and Frère Bénilde show, in Catholic discourse flowers are often associated to virtues or spiritual gifts (also called "charisma, charismata"). The simile between the saint, the elected, and the flower can be traced back to the Bible. For instance, Sirach 39:13 (KJV) reads: "Hearken unto me, ye holy children, and bud forth as a 


\section{Dcula ${ }^{23}$}

Vol 21, No 23 (July 2020) • DOI: 10.12977/ocula2020-31

Jenny Ponzo | The floral smell of sanctity and the semiotics of the halo

rose growing by the brook of the field". ${ }^{4}$ This tradition continues across the centuries and becomes more articulated. In the Middle Ages, the encyclopedia associating flowers to spiritual qualities was wide, on the side of both the signifier (species of flowers) and of the signified (spiritual qualities) involved. The flowers most often associated with spiritual qualities are mainly three, namely the rose, the lily, and the violet:

The rose, with its associations of love, joy, and beauty, came to represent all of the passionate, joyful aspects of medieval religious personification; the lily, its cooler aspects, purity and chastity: the violet, the humility and patient virtues of the Christian life. The literature of the Middle Ages offers many examples of literary flower personification in which these three flowers, along with other popular flowers such as the periwinkle, primrose, and marigold (calendula), represent Christian virtue and the abstract qualities of major saints. Those virtues derive from the qualities of the flowers - color, odor, growth habits, uses - making them strongly iconic. (Seaton 1989: 686)

The personification of flowers finds its maximum expression in a genre of disputatio or certamen, mimicking a dispute between two flowers which enumerate their respective virtues in order to demonstrate their superiority over the other. A typical example is the dispute between the rose and the violet (Marinoni 2007; Seaton 1989: 687). This tradition is connected to the development of a "language of the flowers", both inside and outside of the religious sphere. References to the language of flowers can be found across painting, heraldry, and literature. The study of this code was particularly developed in the $19^{\text {th }}$ century, when numerous treatises analyzed the symbolic meaning of flowers, and in some cases hypothesized its universal validity (Goody 1993: 232-253).

The association between charismata and flowers goes beyond literature and verbal language and finds a parallel in liturgy and ritual practice. In the Middle Ages, flowers were dropped from above in the churches during the Pentecost Mass to symbolize the descent of the charismata. ${ }^{5}$

The reasons for the association of flowers and charismata seem to be mainly two. The first is a reason of iconic similarity: flowers are the most beautiful and delicate part of the plant just as virtues and spiritual gifts are the best part of the human person. The second reason has to do with a specific hierarchy of the senses characterizing Catholic culture, in which the smell is considered less sensuous and closer to the immateriality of spirit than sight. ${ }^{6}$ This concept is echoed in Catholic liturgy:

4 On the plants and flowers in the Bible, see also Volli in this volume.

5 Flowers "Venivano fatti piovere dall'alto durante la Messa di Pentecoste ([detta anche] Pasqua delle Rose) per significare la pioggia dei carismi dello Spirito Santo. [...]" (Cattaneo 1950: 1399).

6 The consideration of sight as a sense more directly connected to the material world is coherent with the tradition of iconoclasm in the Abrahamic religions. See Goody (1993: chapters IV-VI). 


\section{Pcula ${ }^{23}$}

Vol 21, No 23 (July 2020) • DOI: 10.12977/ocula2020-31

Jenny Ponzo | The floral smell of sanctity and the semiotics of the halo

Secondo il regolamento liturgico della Chiesa cattolica i fiori devono anche ornare le urne dei santi nelle chiese e il feretro durante i funerali di bambini, per simboleggiarne la purezza.

I fiori sono dunque un segno di purezza e di innocenza, rappresentate specialmente dal loro profumo, intenso anche se incorporeo, come lo spirito. Siccome sono la parte più bella della pianta, nella tradizione cristiana i fiori simboleggiano la parte più bella ed elevata della persona umana: il fiore rappresenta il "carisma", il dono spirituale che caratterizza il santo (Cattaneo 1950: 1399).

\section{The fragrance of sanctity: a metonymical index}

The connection between saints and smells also interests a semiotic level exceeding the metaphoric association exposed above. Indeed, in Catholic hagiographic literature there is a recurring reference to the charisma of the osmogenesis, namely the supernatural capacity of holy people, both alive and dead, to emanate wonderful perfumes. This celestial perfume is often described as a smell of flowers, even though a number of other kinds of smells make their appearance, from spices like cinnamon and clove, to myrrh (which is a natural gum or resin), to supernatural and ineffable fragrances.

This passage from the metaphorical identification of flowers and charisma to the association of charisma to a perceivable smell has two consequences. Firstly, in this particular association, flowers lose their centrality and constitute one type in a wider range of perfumes associated with exceptional spiritual qualities. Secondly, in the analyzed discourse, this association is not just metaphorical or, in other words, iconic, like in the above-mentioned metaphor, but is described as being actually perceivable: it is therefore indexical in nature and works as a metonym, i.e. a pars pro toto, a perceptible sign indicating the spiritual body of the saints, a trace which in many cases persists after their passage in places, or remains attached to their mortal remains and belongings after their death.

The association of holy people and sublime odors has ancient roots; it can be found as back as in Egyptian and Greek culture. For instance, Amon Ra was supposed to emanate a divine fragrance that pervaded his temple and the places of his apparition, and Greek literature commonly attributes a divine perfume to the deities (Deonna 2003: 7-22). This theme is inherited by Christian hagiography, which presents a rich collection of saints emanating extremely good fragrances during their life, or in the moment of their death, or through their corpse or relics. ${ }^{7}$ For instance, according to Catholic tradition, when saint Teresa of Avila (1515-1582) died, her convent cell was pervaded by an odor of lily (Marchis 2006: 38). Similarly, the scent of rose in saint Rose of Viterbo's (1233-1251) room persisted even four hundred years after her death (Deonna 2003: 186). The Golden Legend narrates moreover that angels offered saint Cecilia and her husband Valeriano fragrant garlands

7 For an accurate cataloguing of these types of fragrant saints, see Deonna (2003), and especially the annexes (Deonna 2003: 93-196). 


\section{Dcula ${ }^{23}$}

Vol 21, No 23 (July 2020) • DOI: 10.12977/ocula2020-31

Jenny Ponzo | The floral smell of sanctity and the semiotics of the halo

of roses and lilies which they passed around their neck: the people around them could smell the flowers' perfume but could not see the garlands (Origoni 2000: 39-40). Another - and far more recent - saint interested by osmogenesis is Pio of Pietralcina (1887-1968). Eye-witnesses ${ }^{8}$ report that his body emanated a perfume of either violet, a mélange of rose and violet, strawberry, or carnation. This particular quality can also be found in Oriental traditions. For instance, in Qigong, a tradition combining traditional Chinese medicine, martial arts and philosophic traditions like Buddhism and Taoism, there are many testimonies of perfumes of herbs and other good fragrances mysteriously emanated by the masters, and there is a branch (apparently an ancient and secret practice of monks nowadays disclosed and openly taught in Western countries) called "Fragrant qigong" because "when exercising, the person can notice a fragrant smell". ${ }^{9}$

The so-called "odor of sanctity" works therefore undoubtedly as an index. What is to be determined, however, is whether the relationship between the sign (the perfume) and its referent (holiness) is conceptualized as actually physical in nature. Indeed, in a number of accounts it seems to be merely physical, while in others the physical materiality of the sign (and therefore its physical perception) is less certain. Indeed, in the Catholic literature, a number of sources interprets the odor of sanctity as a spiritual (i.e. immaterial) odor, and its perception as a spiritual, rather than a sensorial (i.e. olfactory) capacity. This idea is connected with the above-mentioned postulation of the capacity of smell to mediate between the material world and a transcendent and spiritual dimension,,$^{10}$ but increases the immateriality of perception to

8 The first testimony mentioning saint Pio's fragrance was Nina Campanile, one of his spiritual daughters. Even the delegate of the Holy Office Raffaello Carlo Rossi, sent to inquire about the Capuchin friar, reported that his stigmata emanated a perfume of violet. See Mischitelli (2015: 841-842) and Castelli (2008). I thank Francesco Galofaro for the useful conversation about Pio of Pietralcina and his charisma.

9 Just one example quoted out of the numerous available on the Internet: $<$ https://www.qi.org/fragrant/frag1.PDF>.

10 The idea of smell as a sense mediating between the world and the spiritual domain is well-rooted in the common encyclopedia, at least in countries with a Catholic background. This emerged clearly during a small fieldwork carried out in the framework of the project NeMoSanctI: in occasion of a seminar about the Christian symbolism of flowers (held during the European Fascination of Plants Day 2019 and entitled "Fiori dell'anima - La simbologia dei fiori nell'immaginario Cristiano"), we asked the public (composed of lay men and women of different ages, education, and social status) to smell some flower essences and to write down anonymously the thought that those essences evoked to them. Two of the most significant reflections read: "I fiori con la bellezza e il profumo rapiscono i nostri sensi, ma li trascendono anche, generando emozioni profonde, evocando ricordi, suscitando pensieri: ci portano oltre. 'Dissi al mandorlo parlami di Dio e il mandorlo fiorì' (the last sentence is a quotation from the poet Nikos Kazantzakis); "Fiore di campo/ o rosa di giardino/ tutto ci porta una scintilla del divino. / Nel nostro mondo/ anche noi portiamo/ un'eco che viene da lontano./Vita silente/ sembra quasi assente/ solo per chi non vede e non sente niente." (this second testimony, written as a poem, seems to allude to spiritual senses similar to those described by Bonaventure in the quoted passage). 


\section{Dcula ${ }^{23}$}

Vol 21, No 23 (July 2020) • DOI: 10.12977/ocula2020-31

Jenny Ponzo | The floral smell of sanctity and the semiotics of the halo

the point of postulating the existence of immaterial odors and "spiritual senses" working in the same way as physical senses. This is clearly stated, for instance, by Bonaventure of Bagnoregio (1221-1274, one of the main Franciscan theologians, venerated as a saint by the Catholic Church), in his masterpiece Itinerarium Mentis in Deum ("Journey of the Soul into God", chapter 4), composed in 1259:

Therefore the soul, believing, hoping and loving Jesus Christ, who is the incarnate, uncreated and inspired word, that is the way, the truth and the life: while through faith it believes in Christ as in the uncreated Word, which is the Word and splendor of the Father, it recovers its spiritual hearing and sight, hearing to perceive the sermons of Christ, sight to consider the splendors of His light. Moreover when by hope it longs to capture the inspired Word, through desire and affection it recovers its spiritual smell. While by charity it holds fast the incarnate Word, as one taking delight from Him and as one passing over into Him though ecstatic love, it recovers taste and touch. With which senses having been recovered, while it sees and listens to its spouse, it smells, tastes and embraces Him, as a bride can sing repeatedly the Canticle of Canticles, which had been written for the exercise of contemplation according to this fourth step, which no one lays hold of, except he who accepts it, because there is more in affectual experience than in rational consideration. For on this step, with its interior senses repaired to sense the Most High Beauty, to hear the Most High Harmony, to smell the Most High Fragrance, to take a taste of the Most High Savor, to apprehend the Most High Delectable, the soul is disposed towards mental excesses, that is through devotion, admiration and exultation, accord to those three exclamations, which are made in the Canticle of Canticles. ${ }^{11}$ (Bonaventure of Bagnoregio 2002: 17-18)

According to Bonaventure, therefore, the perception through the spiritual senses is an experience connected more with the affective than with the rational sphere. The link between affection and exceptional perfumes becomes central in the $19^{\text {th }}$ century, when psychoanalysts start to interpret the excep-

11 "Anima igitur credens, sperans et amans Iesum Christum, qui est Verbum Incarnatum, increatum et inspiratum, scilicet via, veritas et vita; dum per fidem credit in Christum tanquam in Verbum incarnatum, quod est Verbum et splendor Patris, recuperat spiritualem auditum et visum, auditum ad suscipiendum Christi sermons, visum ad considerandum illius lucis splendors. Dum autem spe suspirat ad suscipiendum Verbum inspiratum, per desiderium et affectum recuperat spiritualem oflactum. Dum caritate complectitur Verbum incarnatum, ut suscipiens ab ipso delectationem et ut transiens in illud per ecstaticum amorem, recuperat gustum et tactum. Quibus sensibus recuperates, dum sponsum suum videt et audit, odoratur, gustat et amplexatur, decantare potest tanquam sponsa Canticum canticorum, quod factum fuit ad exercitium contemplationis secundum hunc quartum gradum, quem nemo capit, nisi qui accipit, quia magis est in experiential affectuali quam in consideration rationali. In hoc namque gradu, reapartis sensibus interioribus ad sentiendum summe pulcrum, audiendum summe harmonicum, odorandum summe odoriferum, debustadum summe suave, apprehendendum summe delectabile, disponitur anima ad mentales excessus, scilicet per devotionem, admirationem et exsultationem, secundum illas tres exclamations, quae fiunt in Canticis canticorum" Bonaventure of Bagnoregio (1994: 134). 


\section{Dcula ${ }^{23}$}

Vol 21, No 23 (July 2020) • DOI: 10.12977/ocula2020-31

Jenny Ponzo | The floral smell of sanctity and the semiotics of the halo

tional and unexplainable emanation of particular fragrances as symptoms of nervous dieseases. ${ }^{12}$ For instance, William A. Hammond

speaks of a hypochondriac whose skin diffused the fragrance of violets; of a hysterical female who smelt pineapple during her paroxysms, and another who perspired on the left half only of her chest, whence she exhaled an odor like that of the iris. [...] Orteschi met with a young girl who exhaled, without any possibility of fraud, a strong odor of vanilla from the commissures of her fingers. [...] All these are examples of disordered innervation. Thus, as Hammond remarks, we perceive that the phrase 'odor of sanctity' is not a mere figure of speech; it embodies the idea of a holy neurosis, which imparts to the skin a perfume more or less agreeable - at least during the actual access of the devotional ecstatic paroxysm. (Monin 1885: 212) ${ }^{13}$

This motif finds a parallel in Italian literature, in a novel by Luigi Capuana entitled Profumo, featuring the character of a woman who, afflicted with a nervous disease due to her conjugal problems, in the moments of major upset emanates a perfume of orange blossom. ${ }^{14}$

\section{The semiotics of the "halo"}

In the tradition under consideration, the perfume is a particular type of ring, or halo, or aura, intended as a sign surrounding a person and indicating the condition of his or her spirit. All type of halo can be defined as a manifestation translating into perceptible signs (either visual or olfactory) an inner state, which otherwise would not be directly perceptible through the senses.

Many cultures posit the existence of a spiritual halo surrounding human beings. The term "aura" is used for instance in mystics, esotericism, parapsychology and New Age religions to indicate a radiation emanated by the human body, and particularly the head, invisible for most part of the human beings, but perceptible by particularly sensitive persons, who are supposed to also distinguish the different strata composing it and their colors, which vary also according to the health and emotive state of the observed subject (Giovetti 1990: 34-35; Costanzo 1996). Starting from the $19^{\text {th }}$ century, specific photographic techniques have been experimented to capture the aura, but were

12 During the $19^{\text {th }}$ century, the idea took root that the odors work as signs of the person's interiority. For semiotic reflections on this topic, see Perras and Wicky (2013). For a history of the meanings attributed to odors in western culture, with a focus on their social connotations, see Corbin (1982).

13 Monin (1885) constitutes a selection of contents taken from Monin and translated into English.

14 Profumo was first published between July and December 1880 in the periodical Nuova antologia and then as a novel in 1892. In a passage, Capuana, through the character of the doctor conciliating science and Catholic faith, mentions William Hammond and Julian Leopold Ochorowicz as examples of physicians and scientists considering smells as expression of (altered) inner states and postulating that thoughts can translate themselves into odors, thus originating a proper language (Capuana 1977: 63-64). 


\section{Dcula ${ }^{23}$}

Vol 21, No 23 (July 2020) • DOI: 10.12977/ocula2020-31

Jenny Ponzo | The floral smell of sanctity and the semiotics of the halo

never acknowledged by the scientific community at large. The most famous example is probably the technique of the "Kirlian photography", elaborated by Semyon Davidovich Kirlian (1898-1978), who named "aura" the luminosity appearing as a result of the corona discharge surrounding any conductive object placed in a dielectric enclosure at atmospheric pressure within a high voltage/high frequency electric field (Mills 2009).

The halo, intended as a stratum of color or a smell surrounding an object or a person forms a complex semiotic system entailing both spatial and temporal features. Concerning the temporal aspect, the olfactory halo has a durative character, as it often persists after the presence of its object. In this sense, the phenomenon of osmogenesis is similar to the aftertaste in the gustative experience. In his "Journal of a beer drinker", Floch (2006: 194, translation mine) reflects on the bitter aftertaste of beer and observes:

Actually, bitterness has to do with aspectualization: when one savors a good beer, it reveals itself in the ending and one can taste it at the bottom of the palate. [...] Most of all, bitterness is perceived as something persisting, going beyond: something trespassing the limit, overflowing. An overflowing of taste, just like the abundant foam often provokes a visual overflowing. So, bitterness is a sensible form of the negation of the discontinuity. It remains in the mounth.

Floch attributes this specific codification of the bitter aftertaste to a baroque worldview: "I proposed [...] to define the baroque vision as a language, of which the form of the expression plane would privilege the negation of the discontinuity and the form of the content the negation of continuity" (Floch 2006: 195).

The idea of the halo, therefore, is often connected to memory. This is also observed by Cesare Segre (1993), who was a prominent exponent of the Italian current of structuralist and semiotic literary critique. Segre (1993) comments a corpus of sonnets dedicated to Laura and developing the theme of the "aura" ("breeze") in Petrarch's Canzoniere. Segre (1993: 46-47) observes that the topos of the "aura", which connects with its movement the poet and his beloved who is far away, was recurrent in Provençal poetry, and that Petrarch develops it in particular in the sonnets 196 and 194:

L'accostamento "via aura" è in qualche misura fisico, in misura certo maggiore mentale ("fammi risovenir" 196, 3; "riconosco" 194, 3); e mentale vale spesso, e certo qui, memoriale e persino mnestico. [...] Ma aura è parte di Laura; insomma il vento stesso è, con la sua testura fonica, una parte della donna.

The persistence of the aftertaste creates a temporal continuity between the sign and its object. The same happens with the scent of sanctity in relation to the physical presence of the saint. This relationship is also connected to an idea of authenticity. In order to catch this idea, it is useful to consider the famous definition of aura by Walter Benjamin. Benjamin (1936/1963) refers the notion of aura to a very different subject, namely the artwork, and identi- 


\section{Dcula ${ }^{23}$}

Vol 21, No 23 (July 2020) • DOI: 10.12977/ocula2020-31

Jenny Ponzo | The floral smell of sanctity and the semiotics of the halo

fies it with the artwork's uniqueness, which, he claims, is destroyed in the era of technical reproducibility. The aura is closely connected to the hic et nunc of the artwork materiality and existence, precisely as the olfactive aura of the saint has a connection both temporal and spatial with the dimension of his or her earthly existence, and therefore is unique and "authentic" as that postulated by Benjamin for the artwork. Benjamin describes moreover the aura as the exceptional apparition of a distance. Therefore, the aura is something both surrounding its object and remaining after its material presence, and is perceptible only by taking some distance from its object. Indeed, aura can irradiate only in a condition of contemplative, but also emotive distance, since distance sharpens the desire to catch the essence of something which could vanish or is unattainable (Griffero 2010).

On the topological level, the aura can be described as a contour. Eco (1997) proposes a reflection about contours in relation to their perception and argues for their natural existence: contours surrounding objects are not just an iconographic convention, but actually exist, since their reproduction entails the application of specific techniques, which actually generate surrogate stimuli. Curiously enough, even though Eco's reasoning focuses on visual contours, when he develops this concept he makes an olfactory example:

Chi abbia mai visitato una fabbrica di profumi si sarà trovato di fronte a una curiosa esperienza olfattiva. Tutti (a livello di esperienza percettiva) riconosciamo benissimo la differenza tra l'odore di una viola e quello della lavanda. Ma quando si vogliono produrre industrialmente essenza di viola o di lavanda [...] si mescolano sostanze tali che il visitatore della fabbrica è assalito da una raffica di afrori e maleodoranze insopportabili. Questo significa che per produrre l'impressione del profumo di viola o di lavanda occorre mescolare sostanze chimiche sgradevolissime all'olfatto (anche se il risultato sarà gradevole). Non so se la natura proceda così, ma quello che appare evidente è che un conto è ricevere la sensazione (iconismo fondamentale) di un profumo di viola, e un conto è produrre la stessa impressione. Questa seconda attività richiede la messa in opera di alcune tecniche, onde produrre stimoli surrogati. (Eco 1997: 308)

Eco does not explicitly posit the existence of olfactory contours. However, smells surround the human person, and therefore olfactory contours surely exist. In religious cultures, sometimes this olfactory ring around saintly people smelling exceptionally good is interpreted as a sign indicating their spiritual quality, as in the case of the Catholic idea of osmogenesis. In other traditions, this spiritual quality is perceived and represented as a colored ring. This idea is surprisingly similar to the one expressed by Simmel and mentioned by both Goffman (1956) and Zilberberg (2001) in relation to proxemics. Simmel speaks of

... the feeling (which also operates elsewhere) that an ideal sphere lies around every human being. Although differing in size in various directions and differing according to the person with whom one entertains relations, this sphere cannot be penetrated, unless the personality value of the individual is thereby destroyed. A sphere of this 


\section{Dcula ${ }^{23}$}

Vol 21, No 23 (July 2020) • DOI: 10.12977/ocula2020-31

Jenny Ponzo | The floral smell of sanctity and the semiotics of the halo

sort is placed around man by his honor. Language very poignantly designates an insult to one's honor as 'coming too close': the radius of this sphere marks, as it were, the distance whose trespassing by another person insults one's honor. (Simmel 1950: 321)

In the case under consideration here, the sphere surrounding the person is not primarily connected with honor, but with sacredness, a notion that is connected to a status of separation both etymologically and conceptually: the sphere surrounding in particular saints is perceivable as a "feeling" of their being sacred people, and as such, different, separated from ordinary people.

Reflecting on this issue by applying the topological categories elaborated by Greimas (1984), it results that the relationship between the aura and the person entails a relationship between the inside and the outside: an inner quality irradiates outside of the body in its most immaterial form, and sometimes remains suspended in the air even after the sacred body leaves. The body works therefore as a permeable container of a spiritual content, as the center irradiating this sense of holiness to a peripheral space inhabited by the receivers of the olfactory (or visual) sign. This external halo has also more or less permeable margins and can have different relationships with the body; for instance, it can be a sphere constantly surrounding it, or leaving traces remaining after its passage, it can be perceived by everybody or only by particular individuals.

\section{Conclusion}

The conceptualization of the smell of flowers in Catholic discourse is coded across different semiotic levels. It is possible to hypothesize that the metaphorical reference constitutes the ground zero for this codification: the connection between a flower, its smell, and a spiritual quality is a conceptual nexus that allows a more complete interpretation of the indexical relationship between the saint and the smell of flowers characterizing the charisma of osmogenesis. In turn, osmogenesis entails a close relationship between the body of the saint and the perfume surrounding it and works as a semiotic system entailing both spatial and temporal features.

The charisma of osmogenesis can be considered as the olfactory parallel of the visual manifestation of the spiritual power, which is described in many traditions and is often called "aura". In Catholic tradition, this spiritual power is visually represented through the golden halo (aureola) surrounding the head of the saints. This visual representation, pervasive in Catholic iconography across time, confirms the functioning of the halo as a sign expressing the sacredness of a person, intended as a status of separateness from the ordinary people and of consecration. Indeed, starting from Urban VIII's Decrees, collected and published in $1642,{ }^{15}$ the Catholic Church has carefully regulated the depiction of the halo and established that only canonized saints had the right to be represented with it. As a consequence, the golden halo becomes

15 Decreta servanda in Canonizatione et Beatificatione Sanctorum. 


\section{Dcula ${ }^{23}$}

Vol 21, No 23 (July 2020) • DOI: 10.12977/ocula2020-31

Jenny Ponzo | The floral smell of sanctity and the semiotics of the halo

the official iconographic sign of sanctity, reserved only to the saints explicitly recognized as such by the authority of the Catholic Church. Surely, this spiritual sphere surrounding the person posited by many cultures and traditions and described in either visual or olfactory terms constitutes a challenge for semiotics as an analytical language, and stimulates the research to rethink and maybe widen its reflection on the sense of olfaction and on the frequently described "feeling" of a sphere (of spirituality, of energy, of honor, etc.) surrounding human beings.

A particularly intriguing issue at stake in the semiotic study of the spiritual halo surrounding human beings is to define the way in which cultures conceptualize the borders of the matter. On the one hand, as argued above, Western culture with a Christian background tends to consider olfaction as a sense close to immateriality; on the other hand, however, some modern and contemporary interpretations also tend to establish an intrinsic relationship between olfaction and matter. Fontanille (2004: chapter I), for instance, who refers to the theory by Annick Le Guérer, ${ }^{16}$ considers odor as the emanation of the most intimate part of the alive being, in its flesh and blood. Based on this premise, Fontanille interprets the association, common to many cultures, between sacred beings (e.g. saints, but also sacrificial victims) and fragrances as a figurative syntaxis and a semi-symbolic system relating the exhalation to the "becoming" of the alive being. This "becoming" corresponds to a dynamic process of intimate movements, entailing blood circulation and breath, which are basic vital functions. The fragrances of alive beings thus become the perfume of life itself, counterposed to the immobility of death. The reference to breath seems particularly indicative of this issue: in many cultures we can find references to a "vital breath" related to an idea of "soul" or "spirit". ${ }^{17}$ While in many cases it is possible to find connections between these ideas and the inner and bodily movements of life, not all of these ideas of spirit can be univocally interpreted as figurativizations of basic vital functions. For this reason, it is problematic to apply Fontanille's interpretative key to all the cultures and religions indiscriminately. This is a further proof of the fact that studying olfaction from a cultural semiotic perspective can lead to a more nuanced understanding of the way in which cultures conceptualize the relationship between materiality and immateriality, since the border between body and spirit often appears blurred in the imaginaries connected to olfaction. In the case of osmogenesis, it is undoubtable that odors are connected to the materiality of the body, and that there is an indexical relation between the perfume and the earthly body of the saint; however, the perception of these fragrances is strongly associated to thematic, figurative and passional isotopies connected to spiritual values and to narrative schemes codified as sacred and supernatural, to the point that these perfumes are sometimes believed to be actually immaterial and transcendent, and only perceivable through "spiritual senses". This idea is deeply coherent with the Catholic notion of human being, composed of a

16 See in particular Le Guérer (1998).

17 See in this respect Leone (2013), Yelle (2016: 214). 


\section{Ocula ${ }^{23}$}

Vol 21, No 23 (July 2020) • DOI: 10.12977/ocula2020-31

Jenny Ponzo | The floral smell of sanctity and the semiotics of the halo

body (contingent and made of flesh and blood), and of a soul (eternal and immaterial): one could hypothesize that the indexical relationship between the perfume and the saint concerns of course the person in its totality, but alludes more to the second than to the first component.

\section{Bibliographic references}

Benjamin, Walter

1936 Das Kunstwerk im Zeitalter seiner technischen Reproduzierbarkeit, Frankfurt am Main, Suhrkamp, 1963.

Bonaventure of Bagnoregio

1994 Itinerario della mente verso Dio. Introduzione, traduzione e note di Massimo Parodi e Marco Rossini, testo latino a fronte, Milan, Rizzoli. Engl. trasl. The Journey of the Mind Into God, ed. Jon Van Hofwegen, Grand Rapids, Christian Classic Ethreal Library, <http://www.ccel.org/ccel/bonaventure/ journey.html>.

Capuana, Luigi

1977 Profumo, Casarile, Armando Curcio Editore.

Castelli, Francesco

2008 Padre Pio sotto inchiesta. L'autobiografia segreta, Milan, Ares.

Cattaneo, Enrico

1950 "Fiori", in Enciclopedia cattolica, vol. 5, Vatican City, Ente per l'Enciclopedia cattolica e per il libro cattolico, p. 1399.

Corbin, Alain

1982 Le miasme et la jonquille : l'odorat et l'imaginaire social : XVIIIe-XIXe siècles, Paris, Editions Aubier Montaigne.

Costanzo, Simonetta

1996 Aura. Campo di forza e di energia luminosa, Bussolengo, Demetra.

Deonna, Waldemar

2003 Euodia: croyances antiques et modernes. L'odeur suave des dieux et des élus. Introduction et épilogue par Carlo Ossola, Turin, Nino Aragno Editore.

Floch, Jean-Marie

2006 "Diario di un bevitore di birra", in Bricolage: lettere ai semiologi di terra ferma, ed. by Agnello M. and Marrone G., Rome, Meltemi, pp. 184-200.

Fontanille, Jacques

2004 Soma et séma. Figures du corps, Paris, Maisonneuve et Larose.

Giovetti, Paola

1990 Il paranormale in 200 parole chiave, Milan, Rizzoli.

Goffman, Erving

1956 The presentation of self in everyday life, Edinburgh, University of Edinburgh Social Sciences Research Centre. 


\section{Dcula ${ }^{23}$}

Vol 21, No 23 (July 2020) • DOI: 10.12977/ocula2020-31

Jenny Ponzo | The floral smell of sanctity and the semiotics of the halo

Goody, Jack

1993 The culture of flowers, Cambridge, Cambridge University Press.

Greimas, Algirdas J.

1984 “Sémiotique figurative et sémiotique plastique”, Actes Sémiotiques, 6 (6o), pp. 5-24.

Griffero, Tonino

2010 Atmosferologia. Estetica degli spazi emozionali, Rome and Bari, Laterza.

Le Guérer, Annick

1998 Les pouvoirs des odeurs, Paris, O. Jacob.

Leone, Massimo

2013 "Signs of the Soul: Toward a Semiotics of Religious Subjectivity", Signs and Society, 1 (1), pp. 115-159.

Marchis, Vittorio

2006 Smell. Vizi e virtì nel mondo degli odori, Turin, UTET.

Marinoni, Maria Carla

2007 "La disputa tra la rosa e la viola dopo Bonvesin", ACME - Annali della Facoltà di Lettere e Filosofia dell'Università degli Studi di Milano, LX (III), pp. 137185. <https://www.ledonline.it/acme/allegati/Acme-07-III-14-Marinoni.pdf>.

Mills, Allan

2009 "Kirlian Photography", History of Photography, 33 (3), pp. 278-287.

Mischitelli, Angelo Maria

2015 Padre Pio: un uomo, un santo, Rome, Sovera Edizioni.

Monin, Ernest

1885a "Odors of the skin and its appendages", Journal of Cutaneous Diseases Including Syphilis, 3 (4), pp. 211-216.

1885b Essai sur les odeurs du corps humain dans l'état de santé et dans l'état de maladie: un nouveau chapitre de séméiologie, Pais, G. Carré.

Origoni, Claudia

2000 I simboli floreali nell’iconografia sacra. Storie e leggende, Manduria, Barbieri Editore.

Perras, Jean-Alexandre; Wicky Érika

2013 "La sémiologie des odeurs au XIX siècle: du savoir medical à la norme sociale", Etudes Françaises, 49 (3), pp. 119-135.

Ponzo, Jenny; Rai, Eleonora

2019 "Heroicity and sanctity in Catholic thought from early modern to contemporary age", Ocula <https://www.ocula.it/files/OCULA-FluxSaggiPONZO-RAI-Heroicity-and-sanctity-in-catholic-thought-from-early-modernto.pdf> (accessed 07 May 2020).

Seaton, Beverly

1989 "Towards a Historical Semiotics of Literary Flower Personification", Poetics Today, 10 (4), pp. 679-701. 


\section{Dcula ${ }^{23}$}

Vol 21, No 23 (July 2020) • DOI: 10.12977/ocula2020-31

Jenny Ponzo | The floral smell of sanctity and the semiotics of the halo

Segre, Cesare

1993 "I sonetti dell'aura", in Segre, C., Notizie dalla crisi. Dove va la critica letteraria?, Turin, Einaudi, pp. 43-65.

Simmel, Georg

1950 The Sociologty of Georg Simmel, transl. and ed. by Wolff, K.H., Glencoe, The Free Press.

Therese of Lisieux

1909 Histoire d'une âme, lettres, poésies, Paris, Librairie Saint-Paul.

Yelle, Robert

2016 "Semiotics", in Stausberg, M. and Engler, S. (eds.), The Oxford handbook of the study of religion, Oxford, Oxford University Press, pp. 208-219.

Zilberberg, Claude

2001 "Soglie, limiti, valori", in Fabbri, P. and Marrone, G. (eds.), Semiotica in nuce. Volume II. Teoria del discorso, Rome, Meltemi, pp. 124-138.

Jenny Ponzo è Professoressa associata di Semiotica presso l'Università di Torino, Dipartimento di Filosofia e Scienze dell'Educazione, è la Principal Investigator del progetto NeMoSanctI, finanziato dall'ERC (g.a. 757314; nemosancti.eu), dal 2019 è Direttrice di CIRCe (Centro Interdipartimentale di Ricerca sulla Comunicazione) e Presidente del Corso di Laurea Magistrale in Comunicazione e Culture dei Media. In precedenza, ha svolto attività di ricerca presso l'Université de Lausanne (Svizzera) e la Ludwig-Maximilians-University Munich (Germania). La sua più recente monografia si intitola Religious Narratives in Italian Literature after the Second Vatican Council: a Semiotic Analysis (De Gruyter 2019). 